\title{
Hvorfor hypertriglyseridemi fører til pankreatitt
}

\author{
Det har lenge vært ukjent hvorfor hypertriglyseridemi kan føre til pankreatitt. Vi mener vi har funnet en \\ forklaring. Pankreatitten starter i de eksokrine pancreascellene med en selektiv mitokondrieskade, indusert \\ av frie fettsyrer og oksidativt stress.
}

Hypertriglyseridemi kan gi akutt pankreatitt (1). Patogenesen har lenge vært ukjent. I et samarbeidsprosjekt mellom Rikshospitalet, Norges veterinærhøgskole, Det odontologiske fakultet, Universitetet i Oslo og Umeå universitetet har vi gjort eksperimentelle funn i en dyremodell som gir en mulig forklaring på hvorfor uttalt hypertriglyseridemi kan gi pankreatitt (2-6). Den tidligere over 40 år gamle teorien om årsaksforholdet er uforenlig med våre funn $(7,8)$.

\section{Minkstudier}

Vi har studert patogenesen i en dyremodell. Det er bare kjent én dyremodell der hypertriglyseridemi fører til akutt pankreatitt. Det er hos mink. Vi har benyttet en minkstamme med arvelig lipoproteinasemangel (5). Fettrikt fôr fører hos denne minkstammen alltid til uttalt hypertriglyseridemi og utvikling av akutt pankreatitt (3).

I slike dyr fant vi at de tidligste forandringene opptrådte intracellulært i de eksokrine pancreascellene der mitokondriene selektivt ødelegges (2) (fig 1). Dette stemmer ikke med den 40 år gamle hypotesen som ofte refereres $(7,8)$. Ifølge denne fører høye konsentrasjoner av frie fettsyrer til skade av trombocytter og karendotel i pancreas, som igjen fører til mikrotromber og iskemi i kjertelen. Ifølge våre funn starter det hele med en selektiv mitokondrieskade utløst av frie fettsyrer. Oksidativt stress gir nekrose med autolyse av kjertelvevet.

\section{Frie radikaler}

Vår forklaring bygger på flere typer forsøk. Dyrene ble gitt infusjoner med radioaktivt merkede kylomikroner (4). De intakte kylomikronene ble langsomt tatt opp intracellulært i alle undersøkte vev. Dette i motsetning til normale dyr der kylomikronene hydrolyseres i blodbanene av lipoproteinlipase. Etter opptak blir intakte kylomikroner hydrolysert av lysosomale enzymer med intracellulær frigjøring av frie fettsyrer. Eksokrine pancreasceller har beskjeden kapasitet til å forbrenne fettsyrer fordi cellene i stor grad bruker glukose som energikilde (2). Overskuddet av frie fettsyrer fungerer som respiratoriske frikoblere. Det fører til redusert syntese av ATP og økt produksjon av reaktive molekyler som $\mathrm{H}_{2} \mathrm{O}_{2}$ og frie radikaler (superoksid $\left(\mathrm{O}_{2}^{-}\right)$, hydroksylradikaler $\left(\mathrm{OH}^{-}\right)$) (9). Dette kan forklare at pancreasskaden starter i mitokondriene.

Hvorfor skulle dette særlig skade pancreas? Forklaringen kan være at energibehovet i pancreas er særlig stort. Syntesen av pancreasenzymene gjør at kjertelen syntetiserer mer protein per gram vev enn noe annet organ (10). Dette gjenspeiles også ved den meget store tetthet av proteinsyntetiserende ribosomer i cellene (fig $1 \mathrm{c}$ ).

\section{Klinisk viktig diagnose}

Klinisk kan de hypertriglyseridinduserte pankreatittene vanskelig skilles fra akutt pankreatitt med annen patogenese (11). Man finner ofte liten amylasestigning ved akutt pankreatitt indusert av hypertriglyseridemi (7). Det passer godt med at det ved denne type pankreatitt initialt skjer en mitokondrieskade som nedsetter den ATP-produksjonen som er nødvendig for biosyntesen av fordøyelsesenzymer (2). Antioksidanter har vært forsøkt som behandling ved pankreatitt indusert av hypertriglyseridemi (12). God effekt er rapportert i enkelttilfeller (12), men foreløpig har man ikke hatt tilstrekkelig store kliniske materialer til å konkludere endelig om behandlingseffekten.

For å stille diagnosen er det viktig å ta blodprøve til analyse av blodlipider tidligst mulig i sykdomsforløpet. Ved faste som er en del av standardbehandlingen ved akutt pankreatitt, faller triglyseridnivået raskt de forste 48 timene etter sykdomsdebut (11). Diagnosen er viktig fordi residiv kan forebygges ved behandling av den underliggende hypertriglyseridemien (11).

Bjørn Christophersen
bjorn.christophersen@medisin.uio.no
Randi Sørby
Harald Osmundsen
Gunilla Olivecrona
Knut Nordstoga

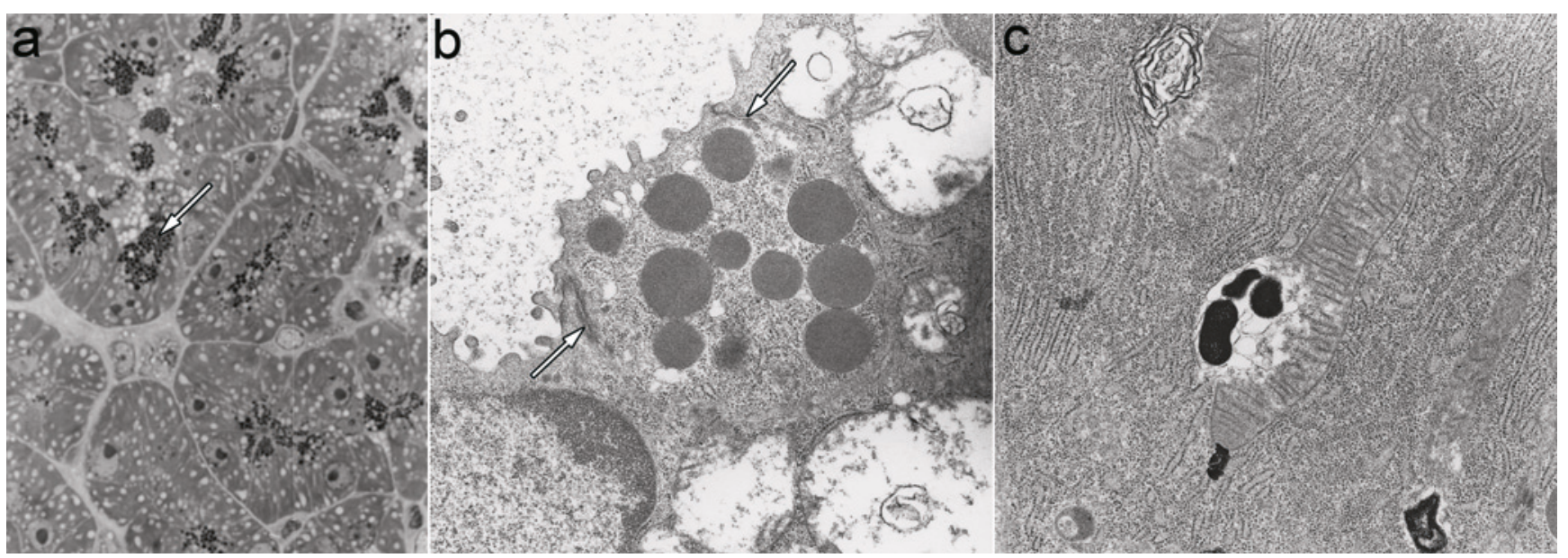

Figur 1 Forandringer i eksokrine pancreasceller hos en 56 dager gammel hyperlipemisk mink som var klinisk frisk og uten makroskopiske forandringer i pancreas. a) Lysmikroskopiske forandringer i et semitynt toluidinblått farget snitt: Vakuoler oppstår tidlig i forløpet, mens zymogengranula (pil) fremdeles er intakte. b og c) l elekronmikroskopet ses svulne mitokondrier med fragmenter av christae, øvrige membraner og desmosomene (intercellulære adhesjonskomplekser) (piler) synes intakte (b), og i mitokondriene finnes myelinlegemer (c) 
Bjørn Christophersen (f. 1933) er spesialist i medisinsk biokjemi og professor emeritus ved Institutt for klinisk biokjemi og Institutt for klinisk medisin, Rikshospitalet, Universitetet i Oslo. Forfatter har fylt ut ICMJE-skjemaet og oppgir ingen interessekonflikter.

Randi Sørby (f. 1970) er veterinær, ph.d., førsteamanuensis ved Seksjon for anatomi og patologi ved Norges veterinærhøgskole og spesialist $\mathrm{i}$ veterinær patologi.

Forfatter har fylt ut ICMJE-skjemaet og oppgir ingen interessekonflikter.

Harald Osmundsen (f. 1946) er professor i biokjemi ved Institutt for oral biologi, Odontologisk fakultet, Universitetet i Oslo.

Forfatter har fylt ut ICMJE-skjemaet og oppgir ingen interessekonflikter.

Gunilla Olivecrona (f. 1952) er professor og avdelingssjef ved Avdeling Fysiologisk kemi, Medicinsk biovetenskap, Umeå universitet. Forfatter har fylt ut ICMJE-skjemaet og oppgir ingen interessekonflikter.
Knut Nordstoga (f. 1927) er professor emeritus, Norges veterinærhøgskole og veterinærpatolog. Forfatter har fylt ut ICMJE-skjemaet og oppgir ingen interessekonflikter.

\section{Litteratur}

1. Cappell MS. Acute pancreatitis: etiology, clinical presentation, diagnosis, and therapy. Med Clin North Am 2008; 92: 889-923, ix-x.

2. Nordstoga $K$, Christophersen B, Ytrehus B et al. Pancreatitis associated with hyperlipoproteinaemia type I in mink (Mustela vison): earliest detectable changes occur in mitochondria of exocrine cells. J Comp Pathol 2006; 134: 320-8.

3. Christophersen B, Nordstoga K, Shen Y et al. Lipoprotein lipase deficiency with pancreatitis in mink: biochemical characterization and pathology. J Lipid Res 1997; 38: 837-46.

4. Savonen R, Nordstoga K, Christophersen B et al. Chylomicron metabolism in an animal model for hyperlipoproteinemia type I. J Lipid Res 1999; 40 : $1336-46$

5. Lindberg A, Nordstoga K, Christophersen B et al. A mutation in the lipoprotein lipase gene associated with hyperlipoproteinemia type I in mink: studies on lipid and lipase levels in heterozygotes. Int J Mol Med 1998; 1: 529-38.

6. Nordstoga K, Sørby R, Olivecrona G et al. Pancreatitis in hyperlipemic mink (Mustela vison). Vet Pathol 2012; 49: 557-61.
7. Graesdal A. Alvorlig hypertriglyseridemi-en viktig årsak til pankreatitt. Tidsskr Nor Legeforen 2008 128: 1053-6.

8. Havel RJ. Pathogenesis, differentiation and management of hypertriglyceridemia. Adv Intern Med 1969: 15: 117-54

9. Rial E, Rodriguez-Sanches L, Gallardo-Vara E et al. Lipotoxicity, fatty acid uncoupling and mitochondrial carrier function. Biochim Biophys Acta 2010;1797:800-6.

10. Goldstein F. Pathophysiology of the pancreas. I: Sodeman WA, red. Pathologic physiology. Mechanisms of disease. Philadelphia, PA: Saunders 1974.

11. Ewald N, Hardt PD, Kloer H-U. Severe hypertriglyceridemia and pancreatitis: presentation and management. Curr Opin Lipidol 2009; 20: 497-504.

12. Heaney AP, Sharer N, Rameh B et al. Prevention of recurrent pancreatitis in familial lipoprotein lipase deficiency with high-dose antioxidant therapy. J Clin Endocrinol Metab 1999; 84: 1203-5.

Mottatt 31.8. 2012, første revisjon innsendt 22.10. 2012, godkjent 27.11. 2012. Medisinsk redaktør Siri Lunde.

Publisert først på nett 18.12. 2012. 